\title{
Female leadership in the context of entrepreneurship in Russia
}

\author{
Liudmila Kiseleva \\ Herzen State Pedagogical University of Russia \\ 48 Moyka Emb., 191186, Saint Petersburg \\ Russian Federation \\ e-mail: kiseleva-1@mail.ru
}

\begin{abstract}
It is estimated that the share of females in management of Russian business companies is probably the highest in the world. Even though, in Russia women prevail among middle managers, while their share remains small in the top-tier management and among the large business owners. A number of women, who own small and medium-sized businesses, grows each year. On the basis of several waves of calculating the Women Business Index it has been discovered, that in Russia favoring of business and social environment at a considerably high level is formed in order to contribute to the female entrepreneurship development. The most common female business spheres are retailing, hotel business, travel industry, FMCG, pharmaceutics, beauty and sports industry, advertisement and media. A phenomenon, called "harmonic entrepreneurship" also became recently tangible. An analysis of the Russian female managers' leadership traits shows, that women do not aim at reaching men in their methods of running the company. Women become successful in business through the creative use of their character and behavior stereotypes, typical for women (a technique of "favors", "tender conflict technologies"). It is common for the Russian women to be very confident in their capability to act in a situation of conflict and a thread of risk. Russian researchers and entrepreneurs consider the "symbiotic" management models as the most effective ones. Within these models the traits of one leader become more complete and correct with the traits of another leader of the opposite gender. We foresee an increase of the female presence in business with the elimination of economic barriers in a lack of financial opportunities for business establishment, as well as overcoming the lack of self-confidence, changes to some inner orientations of the Russian women.
\end{abstract}

\section{Introduction}

Female entrepreneurship represents business activities led and operation by women. The mass emergence of women to entrepreneurship in $20^{\text {th }}$ century can be called a quiet revolution. In the age of post-industrial society special prerequisites are formed for the female entrepreneurship - a transition from production of goods to production of services takes place, and a woman is under special demand from the society in this situation, as the favorable female social as well as sociological traits find thereby their application in various areas of studies including migration, entrepreneurship, management or marketing, just to name a few (see Koudelková and Svobodová 2014; Č́belková et al. 2015; Höschle et al. 2015; Poggesi et al. 2016; ŠabicLipovaca et al. 2016; or Volchik et al. 2018). These traits include: an ability to model new ideas in nonconventional conditions, ability to induce trust, intuition, etc.

Currently, in Russia there is a growing number of not only female top managers, but also female business owners. According to a research of the Grant Thornton International organization, carried out in 2017, a share of women among the Russian companies' managers is $47 \%$, which is the highest value in the world, almost twice the average (Women in Business 2017). Generally, it is related to a success of the women's rights campaign, run at the times of the Soviet Union. The communist party carried out a consistent policy in terms of women's equality. As a result, there appeared more women in such service sectors as healthcare, education, accounting. Besides the leading position in the world in terms of a number of female managerial positions in business, Russia is in the first place in the world in terms of a number of women in the bodies of state authority: there are $72 \%$ of women in the bodies of executive power; $55 \%$ in the bodies of legislative power; $68 \%$ in the bodies of judicial power and public prosecution. The Deputy Chairman of the State Duma of the Russian Federation Mrs. Yarovaya says: "when I meet my colleagues abroad, who are obsessed with the idea of the gender equality, I say, that we are against the gender equality, they become alert. I say: yes, you know, we are for the female privileges in Russia. We are so used to it, that to struggle for equality now means to abandon our privileges" (Newizv 2017).

According to the All-Russian Social Organization "Russian Academy of Business and Entrepreneurship", the female business develops in Russia 1.7 times faster than the male one. On the basis of the experts' assessment in the next 3-4 years $40 \%$ of women will go into private business. Nevertheless, 
there is a strong stereotype among the Russians, that a woman will not cope with her duties, as a man would, because she is dependent from the family, therefore she will not be able to commit herself entirely to work. There are some other stereotypes in Russia, which remain as an obstacle to women's development up the social ladder. It is generally believed that business is rather aggressive, so the male traits are more demanded in it. According to the Russian scholars' research (Chirikova 1998; Malyutina 2002; or Barsukova 1999), an analysis of successful companies shows that neither the male leadership traits, which imply imposing various forms of influence to the employees, nor the female leadership traits, which imply a focus on the personal intuition, are effective, while the entrepreneur will be successful only when he, or she will be able to combine both the male and female traits in herself or himself (Białowąs 2018).

From our viewpoint the male and female leadership traits have the common nature and do not depend directly from the sexual differences. A good manager has a set of both the male and female managerial technologies at his, or her disposal at the same time (Strielkowski and Chigisheva 2018). In addition, business strategies of male and female leaders have certain special features. Women, compared to male entrepreneurs, are oriented to sustainable business strategies and run their business more responsibly and carefully; consider their business more frequently as a self-fulfillment opportunity. The carried out surveys show that the female entrepreneurs, who reach their success in business, feature certain personal distinctive peculiarities: variation of personality's structure, increased psychological tempo-rhythm, high level of working efficiency, etc.

The aim of this paper is to analyze the Russian female entrepreneurs' business activity factors as well as to analyze specific peculiarities of leadership traits demonstration by female entrepreneurs. It concentrates on the culture of entrepreneurship, an entrepreneurial eco-system, and on women's personal traits. The generalization of the empirical research results, carried out by the Russian researchers in various years, enables to characterize the specific features of demonstrating the leadership traits by the Russian female entrepreneurs.

\section{Female entrepreneurship in Russia}

One of the international indicator of female business activity is the Female Entrepreneurship Index (FEI), calculated by the specialists of the Global Entrepreneurship and Development Institute. In 2015 Russia occupied the 56th place among the 70 countries, participating in the research. The essential idea to establish the rating was to compare the countries according to 3 key factors: Entrepreneurial Environment, Entrepreneurial Eco-System, Entrepreneurial Aspirations. According to the assessment of this rating, the Russian women have the lowest scores in terms of the "Focus on export", and the highest ones "Entrepreneurs' education".

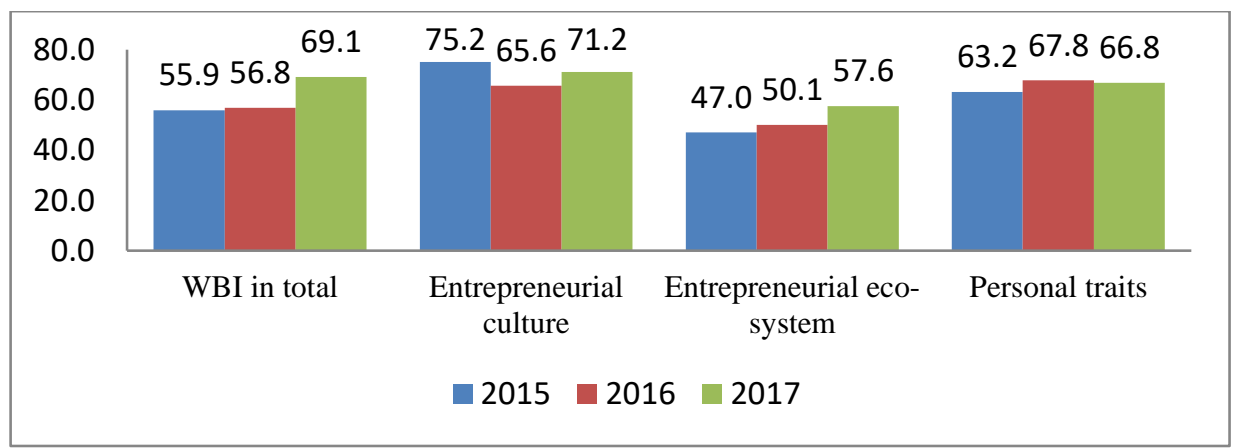

Fig.1. Dynamic values of the WBI index, \% of the respondents

Source: Own results

At the initiative of the non-governmental organization of small and medium business "Opora Russia" the NAFI analytical center has been calculating the Women Business Index (WBI) since 2015. The WBI is the female business activity index, showing the level of the business and social environment favor for the female entrepreneurship development in Russia. The Index is built up according to three key factors: a culture of entrepreneurship (the attitude of the society to the female entrepreneurs); an entrepreneurial eco system (assessment of the business running conditions, availability of the infrastructure, funds, business education, etc.); woman's personal traits (assessment of woman's life quality and her professional skills). The most common spheres for women's career development in Russia are retailing, hotel and travel business, FMCG, pharmaceutics, beauty and sports industry, as well as advertisement and media. As a result of several research waves the positive changes in almost all WBI components may be observed (Fig ure 1 above). 
The index value above 50 points out to the prevalence of positive assessments, below 50 - to the prevalence of the negative ones. Since the starting moment of the research in the year of 2015 the WBI grew for $13 \%$. The WBI dynamics demonstrates a stable improvement of the attitude of the Russian people towards the female entrepreneurship. Women who have no business, became less afraid of a negative reaction from the near and dear ones to their decision to start it. As far as the incentives to start the business activity are concerned, the most prominent is a pursuance of material wealth (Fig ure 2).

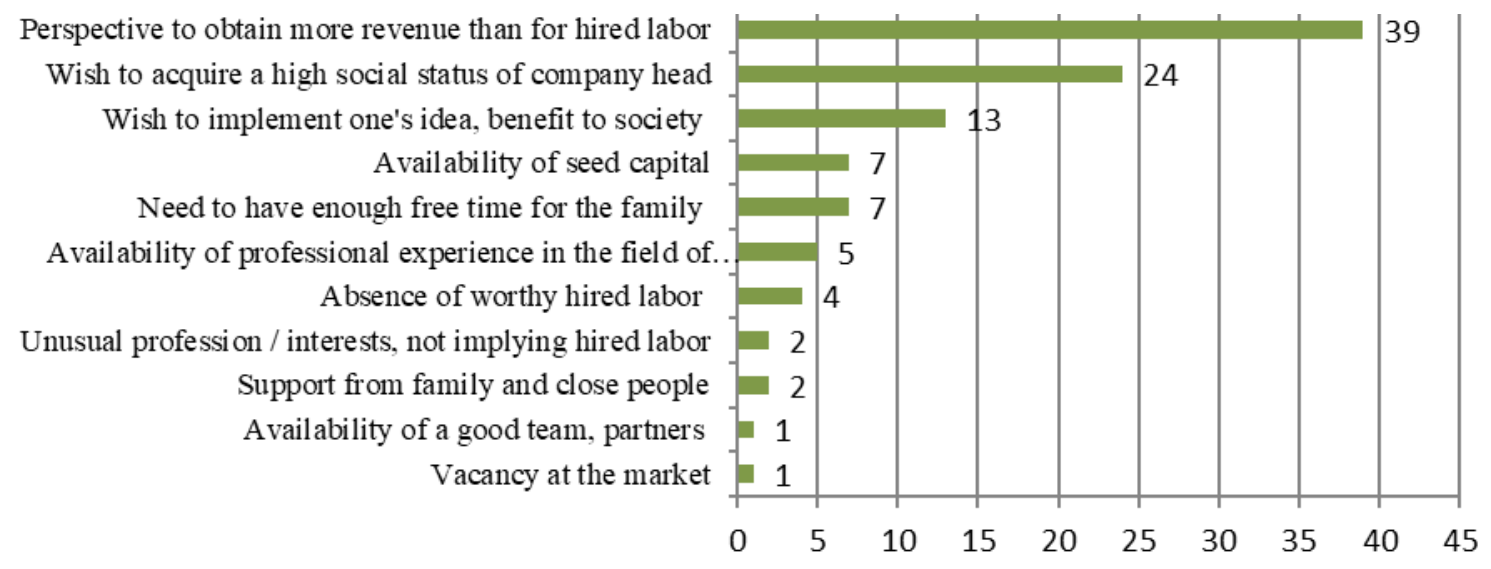

Fig. 2. Incentives to open the own business for the Russian female entrepreneurs, $\%$ of the respondents

Source: Own results

The following incentive in terms popularity is a wish to acquire a status of a company head, which, as a rule, is caused by no wish to be subordinated to someone at hired labour, and in the third place is a wish to fulfil one's idea and benefit the society. The female entrepreneurship in Russia is of the evident socially oriented nature: the majority of business female owners $(59 \%)$ refer their business to the category of social entrepreneurship. Among them $20 \%$ work in the sphere of social security and community assistance, $11 \%$ - in the field of sports and healthy way of living, $9 \%$ - in the sphere of children's and adults' creative education. In this case, it is worth mentioning such phenomenon as "harmonic entrepreneurship". This term covers several business categories, in particular, women, who, as a rule, after the childbirth feel a surge of energy and ideas, which they tend to implement in business, more or less related to children (Garanina 2016). Another category, inclined to such type of entrepreneurship - young people of both genders, who after having seen a lot of bloggers consider themselves well-prepared to business in the Internet and rush into entrepreneurship (Kapitonov, 2018). The topic of harmonic entrepreneurship is not a topic of this work but is worth scientific interest in the future without a doubt.

Female entrepreneurs are optimistic about availability of funds, business education, and infrastructure for children. The majority of women, who applied for loans, note the easiness of their acquisition. It is worth noting, that women own the reputation of the borrowers, who repay their debts almost in $100 \%$ of the cases. It is due to this very reason, why the banks are pleased to collaborate with the companies, headed by women.

The female entrepreneurs note a growing number and quality of business education programs. $41 \%$ of the respondents acquired the supplementary education in the field of business development, $49 \%$ - noted a growth of education availability and 37\% expect improvements in the future (Volkova 2017).

Regarding barriers and obstacles in female entrepreneurship development in Russia, the female respondents, in the first place, note unavailability of financial opportunities (33\%), as well as personal traits, lack of self-confidence (16\%) (Figure 3). 


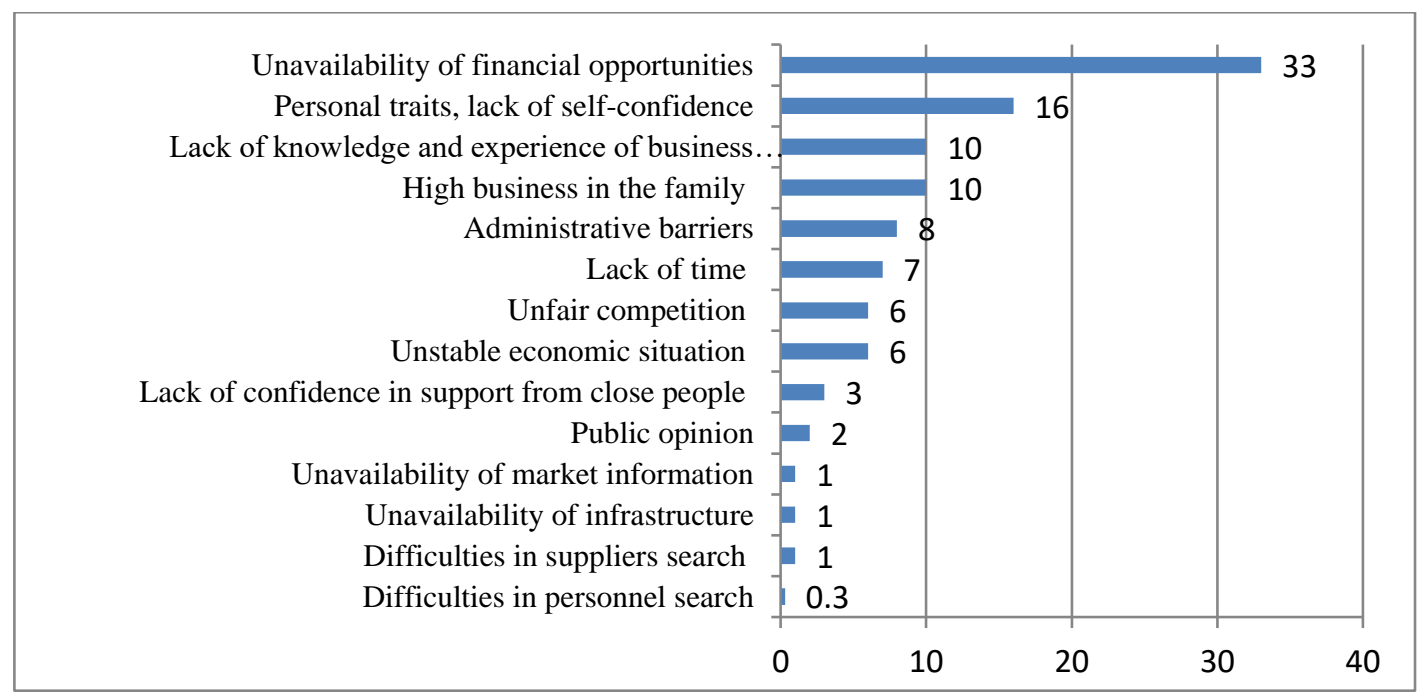

Fig. 3. Obstacles of opening the own business, $\%$ of the respondents. Source: Own results

The research by NAFI shows, that the Russian female entrepreneurs do not yet implement the export potential of their companies, which correlates with the assessments of the Female Entrepreneurship Index. Only $2 \%$ of the respondents have noted, that they export products and services to other countries, while a wish to export them was noted by at least of $21 \%$. Among the major barriers to the exporting activity there are: business model localization (26\%), high competition abroad (14\%) and probable absence of the demand $(11 \%)$. It should be noted, that $26 \%$ are currently aware of the organization, aimed at supporting the exporting companies, and $1 \%$ of the respondents receive this support. We have to conclude, that the female entrepreneurship in Russia is currently excluded from the global processes. So, no more than $6 \%$ female entrepreneurs take part in the international exhibitions and tenders, offered by the international companies.

The "Personal traits" sub-index, included into WBI, consists of women's assessment of their professional skills, their relations within the team, as well as their private life/hobby. The female entrepreneurs, compared to the women, who don't have their own business, assess their professional skills much higher (for 11\%), assess their relations within the team slightly higher (for 3\%). But the women, who don't have their own business, assess satisfaction with their private life (family, hobby) higher. There are two dominant values within the business ladies' life values structure: maternity and personal fulfillment. The life success and the children's welfare is the main value in their lives, while only $1 / 5$ of the female entrepreneurs manage to implement this value. According to the female entrepreneurs, personal fulfillment suggests an opportunity to work with a full commitment, develop one's capabilities, have the material wealth, confidence in the future, opportunity to travel.

\section{Female Managers in Russia: Special Features of Leadership}

The expert assessment of the women's leadership potential and their capabilities to manage a company successfully so far leads, as a rule, to controversial conclusions. The scholars are rather careful in assessing the capabilities of women to reach the highest hierarchies in a company, explaining that, first of all, with an unwillingness to conquer these positions by the women themselves, as well as with rather developed genderrole stereotypes. Women, in their turn, intent to over-estimate the male advantages and under-estimate the advantages of other women and themselves.

The first research in the field of gender leadership aspects was performed in the USA in the 1940s and 1950s. This area started developing rapidly in the 1970s under the influence of the feminist psychology. A Giddens (1995) made a principal distinction between the sexes, claiming, that the institutional difference between the sexes actually separate the mind and emotions. At present, the fields of research in the gender leadership aspects may be divided into three groups.

In the first group the gender factor is considered as the main one. The conceptions, in which the factor of sex is a dominant one at showing the leader's traits, include a conception of a gender flow (Nieva and Gutek 1980), a theory of gender leaders' selection (Chapman 1975), a conception of tokenism (Canter 2008). In order to explain the differences between leaders of different sex Bem (1977) and Spence (2000) engaged an idea of androgyny. The Freudism supporters have a traditional negative attitude towards the female 
leadership, relating it to the non-natural masculine gender role. They consider the female striving for leadership as demonstration of deficiency of a woman, who envies a man.

In the second research group the preference is given to the leadership traits. In the situation-official approach the first place is given not to the sex, but to a position, which person has in a company (Cantor et al. 1998). From their viewpoint, men and women, having the similar positions and successfully playing the similar leader's roles, should not differ considerably from one another either in terms of behavior, or the effectiveness factors. The status theory (the theory of rank expectations) identifies a person in a group and status, held by this person in the society (Ridgeway 2001). The behavioral dynamic exchange model "leaderresearcher" Graen (1995) puts an ability to establish close positive relations with other people to the basis of successful leadership. This model is closely related to a conception of transformational leadership (Bass and Avolio 1994).

The third research group is dedicated to a study of the influence of stereotypes and roles in perception of leaders either of the male, or female gender. The social-role theory of gender differences, offered by A. Eagly $(1990 ; 2003)$, bases on the fact, that leadership, as an initial masculine role, sets up its claims to a person, and a female leader is in the most cases destined for an internal conflict due to a role and gender mismatch in requirements. The "gender management" conception considers protective strategies and techniques of leadership implementation. Among the essential elements there are: ultra-diligence and advanced performance, use of female tricks at running business negotiations, use of "masks" - concealment of emotions and private life from others.

Based on the data of empirical research carried out in Russia and focusing on assessments the Russian female entrepreneurs' managerial opportunities, it can be concluded, that over $70 \%$ of women assess their managerial traits not worse the male ones, while $30 \%$ of the respondents are convinced in their advantage before men in the ability to manage people (Chirikova 1998, p. 44). A high level of women self-assessment of their own leader traits almost coincides with the assessments, given to them by their male subordinates. An inquiry of male vice-presidents of companies has shown a high level of satisfaction of the latter with a female management technique. According to men, women are the most successful in acting in critical situations. The strategy of their business behavior is notable as less ambitious and unpredictable. Over $80 \%$ of male vice-presidents would not like a replacement of the female leader with a male manager by any means.

According to the estimates of men, female managers are noted for important traits: they are able to manage a team based on the "favors" technique, combine the traits of directive and instructive leader in themselves, possess "tender conflict technologies". Over $30 \%$ of the men under immediate subordination to the female managers consider inclination to collective decisions lower risk potential as weak characteristics of female management. The male business partners asses the women as company leaders rather high. $60 \%$ of the expert respondents point out to a high level of responsibility and duty performance of women in business. 30\% note fearlessness, unexpected for women, and ability to act flexibly in unpredictable situations. But, according to $40 \%$ of the male respondents, women surrender men in ambition, which does not enable them to reach big results in business. The assurance of men (40\%) in advantages of the male management over "tender management" are also based on the confidence, that women are "weaker strategic thinkers" and are not able to take the necessary decisions as fast as the situation requires to.

The specific peculiarities of the Russian female leaders lie in the fact, that women do not strive for reaching men in their company management methods. About a half of women suppose, that the men's advantages are located in the environment of strategy and analysis, while in certain implementation of the set goals the woman is a rather efficient strategic thinker. The following can be stated: the Russian woman reaches her success in business not due to the mimicry to the male management style, but due to creative use of her character and behavior stereotypes, typical for women and short time ago considered unacceptable in management. Today, non-traditional management style, humanist management, fits better into the changing conditions of the companies' activities and contributes to a transition to a new managerial paradigm. Its essence is divergence from managerial rationalism towards greater openness and flexibility in terms of continuously changing requirements of the outer environment. It is this very objective, that the woman is capable to cope with in the most productive way.

The research by Chirikova $(1997 ; 1998)$, during which the scales of business and personal traits of entrepreneurs were formed on the basis of the works by Scherbina (2004), enabled to compile a rating of entrepreneur's traits. Some serious differences between men and women were found in terms of perception of the abilities, with the help of which they act and become successful in business. The table below presents the top nine positions from a common row of 25 entrepreneur's capabilities, offered by the researchers (Table 1). 
Table 1. Rating of entrepreneur's capabilities according to male and female entrepreneurs

\begin{tabular}{|c|l|l|}
\hline $\begin{array}{l}\text { Position } \\
\text { in rating }\end{array}$ & \multicolumn{1}{|c|}{ Entrepreneur's capabilities: according to men } & Entrepreneur's capabilities: according to women \\
\hline 1 & $\begin{array}{l}\text { Permanent readiness to changes, ability to cope } \\
\text { with novelties }\end{array}$ & $\begin{array}{l}\text { Capability to make a compromise, run negotiations } \\
\text { flexibly, take positions of other parties } \\
\text { consideration }\end{array}$ \\
\hline 2 & Capability to impose one's position, if necessary & Confidence in self and in one's mission \\
\hline 3 & $\begin{array}{l}\text { Capability to feel at ease and accrue benefits within } \\
\text { the framework of accepted limitations and rules }\end{array}$ & $\begin{array}{l}\text { Ability to act in a situation of conflict and a threat } \\
\text { of risk }\end{array}$ \\
\hline 4 & $\begin{array}{l}\text { Ability to use other people's skills and } \\
\text { capabilities efficiently }\end{array}$ & $\begin{array}{l}\text { Permanent readiness to changes, ability to cope } \\
\text { with novelties }\end{array}$ \\
\hline 5 & $\begin{array}{l}\text { Ability to use ideas of others to implement personal } \\
\text { goals }\end{array}$ & $\begin{array}{l}\text { Ability to make a quick choice } \\
\text { threat of risk }\end{array}$ \\
\hline 6 & $\begin{array}{l}\text { Ability to make an impression, establish and } \\
\text { maintain relations with other people }\end{array}$ & $\begin{array}{l}\text { Ability to use other people's skills and capabilities } \\
\text { efficiently }\end{array}$ \\
\hline 8 & $\begin{array}{l}\text { Confidence in self and in one's mission } \\
\text { Ability to withstand pressure and push, to } \\
\text { defend one's position }\end{array}$ & $\begin{array}{l}\text { Ability to withstand pressure and push, to defend } \\
\text { one's position }\end{array}$ \\
\hline 9 & Ability to live for the now, "here and now" \\
\hline
\end{tabular}

Source: Own results based on Chirikova (1998)

Taking into account, that five bolded entrepreneur's traits out of nine are present in both the male and female parts of the table, a conclusion may be drawn about the common nature of the leadership traits, which are in demand in entrepreneurs at running their own business. The relatively coinciding traits of the male and female entrepreneurs are: confidence in self and in one's mission; ability to act in a situation of conflict and a threat of risk; permanent readiness to changes, ability to cope with novelties; ability to use other people's skills and capabilities efficiently; ability to withstand pressure and push, to defend one's position. The researchers find differences between the male and female business behavior strategies in assessment of the traits, which men place higher, than women: ability to anticipate the moves ahead; ability to feel at ease and accrue the benefits; ability to impose one's position to others, if necessary; ability to set goals; ability to make an impression. These assessments highlight the fact, that the man is a bigger player in business than the woman. He is oriented to dominance and achievement of goals "whatever it takes" (Chirikova 1998: 55). The woman, on the contrary to the man, bases in her achievements on other capabilities, which she assesses higher: capability to manage the capital efficiently; ability to switch fast from one activity to another; ability to make compromises, run negotiations flexibly; ability to live for the now, "here and now".

Comparing the area of matches and differences of the pointed-out traits of the male and female leaders, it becomes obvious, that the Russian women, as well as the female leaders, according to the foreign research (Bynum 2001), are more "rational", "flexible", "compromise-oriented" in their assessments, being able to live for the now. But for the Russian female entrepreneurs the confidence in their ability to act in a situation of conflict and threat of risk is more typical. It witnesses the fact, that the women assess their own capabilities to act rationally under the condition of a threat of risk not lower than the male ones, and are inclined to place this trait to one of the top places in the common row of capabilities. According to some Russian scholars and practical researchers (Chirikova 1998; Roschin and Roschina 1994; Legasova 2015), the "symbiotic" management models, when the traits of one of the leaders are completed and corrected with the traits of the second leader of the different gender, are highly effective. This, however, does not mean, that there are no possible cases of efficient activity by a team, made up entirely with individuals of one gender.

The first model: President (male) - Vice-president (female). Consideration of the existing forms with such a distribution of figures in the management enables to state, that during the joint work according to this model there are the own work principles between the two leaders, building up in the company: 1) the female leader, as a rule, does not use the direct influence methods; 2) the women is able to perform the real influence only after the formation of success potential and trust, without entering into the relations of rivalry and conflict. The rivalry and conflict block the channels of influence and disorder interactions in the company between the first and the second figure; 3) the key re-orientation of the first figure is only possible in case of gradual persuasion and unfocused influence, regardless of the psychological distance and nature of interpersonal influence.

The woman's flexibility in this interaction model is so high, that sometimes leads to a modification of the internal sets, contributing to actualization of the traits, which in isolation from this interaction may not be present in the personality structure at all. As a rule, this interaction model is efficient due to special interpersonal relations, located at the scale "respect-emotional acceptance-devotion" (Chirikova 1998, p. 49). 
The second model: the President (female) - Vice-President (male). The female President state, that this combination is the most efficient, as it enables to assess the situation from various positions and take decisions, basing on various vision, sometimes caused by the inter-gender differences. It is noted, that in case of a woman's taking the first position in a company a man solves the tactical tasks, building up the strategy, following the woman. The area of the functional tasks, solved by the man under this model, is rather broad, but as the woman, he compensates the female management style, becoming sometimes a strategic, or tactical thinker, depending on the situation. Women very much trust the "male assessment" of the situation but prefer to take the final decision independently. In this case, the man as the second figure, actually has a "consultative vote" in taking strategic decisions. The work for the men, as well as for the women, becomes efficient, when he feels a deep respect towards the woman. A need of emotional bond is not necessary, but desirable, though the men demonstrate less effect from emotional dependence in this model, than do the women. The women's professionalism, an opportunity of self-fulfillment, to assert himself in his personal and the others' perception is more important for the men.

\section{Conclusions}

Overall, our results confirm the suggestions that the share of female managers in the Russian companies is the highest in the world. In Russia, women prevail among the owners of small-scale business, as well as among the middle managers, but their share remains low in the top management sector and among the owners of large-scale business. After the analysis of composition of the boards of directors of 20 public companies, leading the Russian Forbs rating it turns out, that among them there are $6.1 \%$ of women. Nevertheless, there are more Russian women, who find themselves in business. Women express their interest towards various fields of economics, predominantly in the sphere of services $(58 \%)$, then - commerce $(28 \%)$ and production (14\%). This field structure is typical for the small-scale and middle-scale business segments as a whole, and women are more frequently involved in social projects, charity, sphere of children's education and upbringing. The phenomenon, known as "harmonic entrepreneurship" keeps broadening.

For the period of calculating the Women Business Index in Russia in 2015-2017 there are positive changes noted in terms of all components of the index. The main incentive for women to get engaged in business is a perspective to acquire a larger revenue, than at the hired labor. Regarding the barriers to start the own business there is an economic factor - a lack of financial opportunities. Also, among the top five barriers there are factors of a strongly cut gender nature - personal traits, a lack of self-confidence, as well as high business in the family. The peculiarity of the Russian women is that, women are far from always of having an internal inclination to take the leading positions, which is caused by the special features of upbringing in the Russian families. For the majority of the female managers the dominant life values are their children's welfare and success, which is, according to women, is poorly combined with high business at work and need of high commitment in business.

At the same time, the research, related to the women, already engaged in business, shows a high level of self-assessment of female entrepreneurs, which is confirmed by a high assessment of women's professionalism, given by the male business partners and male subordinates. The Russian female leaders, as well as women in other countries, are oriented towards the traits of "compromise", "confidence" at a high influence of the "flexibility" traits at the background of the developed capability to dominate. For the Russian women a high confidence in their capability to act efficiently in the situation of conflict and threat of risk is rather typical, while the women define this ability as the most important entrepreneur's capability.

From the viewpoint of the Russian business representatives, the most efficient management models in business are "symbiotic" models, where the traits of one of the leaders are supplemented and corrected with the traits of the second leader of different gender. The women, who work in entirely female teams, in $60 \%$ of cases express a wish to share the burden of responsibility for management of the company together with a man, and are sure, that it may give good results for the company's activity.

Drawing a conclusion of the performed analytical work, we assume, that presence of women in the Russian business will grow due to several reasons: firstly, the female population in Russia grows much faster, than the male one, therefore, there is annually growing number of companies, headed by women, due to purely demographic reason; secondly, as the service level and women's wealth grow, the change of mentality takes place, there is more time for career development, and there are more women, successfully building their business; thirdly, the humanist management becomes valuable in the contemporary society, an ability to negotiate becomes more valuable, while the aggressive style of running the business may be rarely met, which contributes to increasing the share of women as the business owners. 


\title{
References
}

\begin{abstract}
Aleksandrov VA, Veschugina SS, Scherbina VV, Sobol EI, Management of human resources: management and consulting, $1^{\text {st }}$ edn. (Moscow: Independent Institute of Civil Society, 2004), $520 \mathrm{p}$.

Barsukova SYu (1999) Special features of female entrepreneurship. Techniques of adaptation of population to a new social-economic situation in http://ecsocman.hse.ru/data/692/692/1219/005.BARSUKOVA.pdf. Accessed 20 May 2018
\end{abstract}

Bass BM, Avolio BJ (1994) Shatter the glass ceiling: Women may make better managers. Human resource management 33(4): 549-560. doi: 10.1002/hrm.3930330405

Białowąs P (2018) Enterprise restructuring: a quality management paradigm. Czech Journal of Social Sciences, Business and Economics 7(1):24-28. doi: 10.24984/cjssbe.2018.7.1.3

Biggart NW, Hamilton GG (1987) An institutional theory of leadership. The Journal of Applied Behavioral Science 23(4): 429-441. doi: 10.1177/002188638702300401

Borisova O, Sterkhova O (2011) Women as valuable asset. https://newizv.ru/news/society/28-122017/rossiya-vozglavila-reyting-stran-s-samym-bolshim-chislom-zhenschin-rukovoditeley-9df35d83-6c7f4746-b968-b8cfd9cbe088. Accessed 24 May 2018

Bynum V (2001) An investigation of female leadership characteristics. Doctoral dissertation, Capella University.

Č́aelková I, Abrhám J, Strielkowski, W (2015) Factors influencing job satisfaction in post-transition economies: the case of the Czech Republic. International Journal of Occupational Safety and Ergonomics 21(4):448-456. doi: 10.1080/10803548.2015.1073007

Canter RM, Men and women of the corporation, $2^{\text {nd }}$ Revised ed. edition. (New York: Basic books, 1993), $416 \mathrm{p}$.

Cantor D, Bernay T, Stones J, Woman in Power, $1^{\text {st }}$ edn. (PT. Gramedia Pustaka Utama: Jakarta, 1992), $120 \mathrm{p}$.

Chapman JB (1975) Comparison of male and female leadership styles. Academy of Management Journal, 18(3):645-650. doi: 10.2307/255695

Chirikova AE, Woman in the company lead, $1^{\text {st }}$ edn. (Moscow: RAS Sociology Institute Publishing House, 1998), $358 \mathrm{p}$.

Eagly AH, Johannesen-Schmidt MC, Van Engen ML (2003) Transformational, transactional, and laissezfaire leadership styles: A meta-analysis comparing women and men. Psychological Bulletin 129(4):569591. doi: 10.1037/0033-2909.129.4.569

Eagly AH, Johnson BT (1990) Gender and leadership style: A meta-analysis. Psychological Bulletin 108(2), 233-256. doi: 10.1037/0033-2909.108.2.233

Garanina E (2016) Maternity business: what companies are opened by young mothers. Company's secret. https://secretmag.ru/trends/tendencies/mamy.htm. Accessed 18 May 2018

Giddens A (1994) Transformation of intimacy: sexuality, love and eroticism in modern societies, $1^{\text {st }}$ edn. (London: Blackwell, 1993), 212 p. doi: 10.1177\%2F144078339403000218

Graen GB, Uhl-Bien M (1995) Relationship-based approach to leadership: Development of leader-member exchange (LMX) theory of leadership over 25 years: Applying a multi-level multi-domain perspective. The leadership quarterly 6(2):219-247. doi.org/10.1016/1048-9843(95)90036-5

Höschle F, Strielkowski W, Tcukanova O, Welkins E (2015). Locational preference and unemployment of Asian-born immigrant in the US metropolises. Geographica Pannonica 19(2):58-63. doi: 10.5937/GeoPan1502058H

Kapitonov A (2018) Harmonic entrepreneurship. Business Petersburg. http://blog.dp.ru/post/11881/. Accessed 28 May 2018

Koudelková P, Svobodová P (2014) Knowledge creation \& sharing as essential determinants of SMEs innovation. International Economics Letters 3(1): 12-20. doi: 10.24984/iel.2014.3.1.3 
Legasova I (2015) Business with female forms. http://mediametrics.ru/articles/view.html?id=447. Accessed 12 May 2018

Malyutina TG (2002) Distinctive features of female entrepreneurship in Russia. Female entrepreneurship in economy of Russia and CIS, $1^{\text {st }}$ edn. (Moscow: Konversiya i zhenshchiny, 2002), 134 p.

Newizv (2017) Russia led the rating of countries with the largest number of female entrepreneurs. https://newizv.ru/news/society/28-12-2017/rossiya-vozglavila-reyting-stran-s-samym-bolshim-chislomzhenschin-rukovoditeley-9df35d83-6c7f-4746-b968-b8cfd9cbe088. Accessed 7 May 2018

Nieva VF, Gutek BA (1980) Sex effects on evaluation. Academy of management Review 5(2): 267-276. doi:10.5465/amr.1980.4288749

Poggesi S, Mari M, De Vita L (2016) What's new in female entrepreneurship research? Answers from the literature. International Entrepreneurship and Management Journal 12(3):735-764. doi: 10.1007/s11365015-0364-5

Ridgeway CL (2001) Gender, status, and leadership. Journal of Social issues 57(4): 637-655. doi: 10.1111/0022-4537.00233

Šabic-Lipovaca A, Strielkowski W, Bilan Y (2016) Intertemporal substitution and labour supply of Bosnian SME's. Amfiteatru Economic 18(43), 634-653.

Strielkowski W, Chigisheva O (2018) Social, Economic, and Academic Leadership for Sustainable Development of Business and Education in the Future: An Introduction. In: Strielkowski W., Chigisheva O. (eds.) Leadership for the Future Sustainable Development of Business and Education. Springer Proceedings in Business and Economics. Springer, Cham, pp. 3-8. doi: 10.1007/978-3-319-74216-8_1

The 2015 Female Entrepreneurship Index (2015) https://thegedi.org/research/womens-entrepreneurshipindex/. Accessed 8 May 2018

Volchik V, Klimenko 1, Posukhova O (2018) Socio-economic sustainable development and the precariat: a case study of three Russian cities. Entrepreneurship and Sustainability Is sues 6(1):411-428. doi: 10.9770/jesi.2018.6.1(25)

Volkova O (2017) New wave: 7 facts about female entrepreneurship in Russia http://www.forbes.ru/forbes-woman/340257-novaya-volna-7-faktov-o-zhenskom-predprinimatelstve-vrossii. Accessed 19 May 2018

Women Business Index (2018) http://womanopora.ru/proekty/indeks-zhenskoj-predprinimatelskojaktivnosti-(wbi)/. Accessed 21 May 2018

Women in business (2017) https://www.grantthornton.global/en/insights/diversity/. Accessed 5 May 2018 